Vos, H.M.M., Delft, D.H.W.J.M. van, Kleijn, M.J.J. de, Nielen, M.M.J., Schellevis, F.G., LagroJanssen, A.L.M. Selective prevention of cardiometabolic diseases in general practice: attitudes and working methods of male and female general practitioners before and after the introdtiction of the Prevention Consultation guideline in the Netherlands. Journal of Evaluation in Cliniqalive Practice: 2014, 20(4), 478-485

\begin{tabular}{|l|l|}
$\begin{array}{l}\text { Postprint } \\
\text { Version }\end{array}$ & 1.0 \\
\hline Journal website & http://onlinelibrary.wiley.com/doi/10.1111/jep.12179/abstract \\
\hline Pubmed link & http://www.ncbi.nlm.nih.gov/pubmed/24910340 \\
\hline DOI & 10.1111/jep.12179
\end{tabular}

This is a NIVEL certified Post Print, more info at http://www.nivel.eu

\title{
Selective prevention of cardiometabolic diseases in general practice: attitudes and working methods of male and female general practitioners before and after the introduction of the Prevention Consultation guideline in the Netherlands
}

Hedwig M.M. Vos MD ${ }^{1}$, Diane H.W.J.M. VAN DelfT BSC ${ }^{2}$, MiRiam J.J. DE KLEIJN MD PHD $^{3}$, MARKUS M.J. NIELEN PHD ${ }^{4}$, FRANÇOIS G. SCHELLEVIS MD PHD ${ }^{5,6}$, ANTOINE L.M. LAGRO-JANSSEN MD PHD ${ }^{7}$

1. Department of Primary and Community Care, Gender and Women's Health, Radboud UMC, Nijmegen, The Netherlands

2. Department of Primary and Community Care, Gender and Women's Health, Radboud UMC, Nijmegen, The Netherlands

3. Department of Primary and Community Care, Gender and Women's Health, Radboud UMC, Nijmegen, The Netherlands

4. NIVEL (Netherlands Institute for Health Services Research), Utrecht, The Netherlands

5. NIVEL (Netherlands Institute for Health Services Research), Utrecht, The Netherlands

6. Department of General Practice and Elderly Care Medicine/EMGO Institute for Health and Care Research, VU University Medical Centre, Amsterdam, The Netherlands

7. Department of Primary and Community Care, Gender and Women's Health, Radboud UMC, Nijmegen, The Netherlands

\begin{abstract}
Rationale, aims and objectives

In 2011 the module cardiometabolic risk of the Prevention Consultation guideline was introduced in the Netherlands in order to prevent cardiometabolic diseases. We aimed to compare attitudes and working methods of Dutch general practitioners (GPs) towards selective prevention of cardiometabolic diseases before and after the introduction of the guideline and to study the effect of GP gender on these attitudes and working methods.
\end{abstract}

Methods 
Vos, H.M.M., Delft, D.H.W.J.M. van, Kleijn, M.J.J. de, Nielen, M.M.J., Schellevis, F.G., LagroJanssen, A.L.M. Selective prevention of cardiometabolic diseases in general practice: attitudes and working methods of male and female general practitioners before and after the introdtration of the Prevention Consultation guideline in the Netherlands. Journal of Evaluation in Cliniqalive Practice: 2014, 20(4), 478-485

We compared attitudes and working methods in prevention of cardiometabolic diseases in a cross-sectional survey among Dutch GPs in 2013 to the results of a comparable study performed in 2008.

Results

Both in 2008 and 2013 30\% responded. In 2013, more GPs reported to actively invite patients for preventive measurements. Thirty per cent of the GPs implemented the module cardiometabolic risk. In 2013, less GPs reported that it is worthwhile to make an effort to detect patients at increased risk for cardiometabolic diseases, and more GPs suggested that prevention may be performed by other stakeholders compared with 2008. Financial support and evidence for prevention programmes were mentioned as main facilitators for prevention. In 2013, more male than female GPs actively invite patients for preventive measurements.

Conclusions

More GPs report active preventive working methods after the introduction of the Prevention Consultation guideline, but only 30\% implemented the guideline. More male than female GPs actively invite patients for preventive measurements. Compared with 2008 less GPs think it is worthwhile to make an effort to detect patients at increased risk and more GPs are willing to delegate preventive actions to other health institutions in 2013. As financial support and evidence for prevention are important facilitators for prevention, further research of the effectiveness of the guideline in preventing cardiometabolic diseases is necessary, and political choices have to be made in order to financially facilitate selective prevention in general practice.

\section{INTRODUCTION}

Cardiometabolic diseases, including cardiovascular disease, diabetes mellitus type 2 and chronic kidney diseases, are responsible for a quarter of all deaths worldwide and are common diseases in the Netherlands [1-4]. Prevention of these diseases will not only reduce morbidity and mortality, but it will also improve quality of life [1]. General practitioners (GPs) are in the ideal position to deliver preventive medicine by enquiring about patients' lifestyles and providing information and counselling about risk factors [5]. Every Dutch inhabitant is listed with a GP and about $77 \%$ of all people consult their GP at least once a year [6,7]. These contacts offer opportunities for preventive care [8]. Moreover, Dutch GPs are already involved in systematic prevention programmes such as influenza vaccination and cervical cancer screening.

In March 2011, the module cardiometabolic risk of the guideline Prevention Consultation has been introduced in general practice in the Netherlands to improve the early detection and management of patients with an increased risk for cardiometabolic diseases. As the diversity in available health checks was confusing for the general public, the Dutch Heart Foundation, the Kidney Foundation and the Diabetes Fund together with the Dutch College of GPs, the National Association of GPs and the Dutch Association of Occupational Medicine joined forces to develop 
Vos, H.M.M., Delft, D.H.W.J.M. van, Kleijn, M.J.J. de, Nielen, M.M.J., Schellevis, F.G., LagroJanssen, A.L.M. Selective prevention of cardiometabolic diseases in general practice: attitudes and working methods of male and female general practitioners before and after the introdtion 7 of the Prevention Consultation guideline in the Netherlands. Journal of Evaluation in Cliniqglive Practice: 2014, 20(4), 478-485

an evidence-based tool for GPs in facilitating selective prevention of cardiometabolic disease $[1,9,10]$. The module consists of a questionnaire and, if indicated, additional measurements. Each patient listed in the practice between the age of 45 and 70 years old is invited to fill in the questionnaire. In a study to assess the rates of newly diagnosed hypertension, hypercholesterolemia, diabetes mellitus and chronic kidney disease 392 patients (64\%) were estimated to have a high risk and were referred to the practice; $36 \%$ consulted the GP. In $22 \%$ of these patients a new diagnose was identified [11].

To successfully implement programmes to prevent cardiometabolic diseases, we need to know GPs' attitudes towards selective prevention. In 2008, before the publication of the guideline Prevention Consultation, a cross-sectional survey of attitudes and working methods of Dutch GPs in prevention of cardiometabolic diseases was carried out. GPs showed a positive attitude towards prevention of cardiometabolic diseases. They considered that prevention should be focused on patients at high risk [2].

Studies show that female GPs practice differently than male GPs [12,13]. Female GPs have longer patient visits and engage in more patient-centred communication. They provide more counselling and immunization services, and female GP gender is associated with a greater likelihood of receiving preventive counselling by both male and female patients $[14,15]$. The GP profession is becoming feminized [12]. In the Netherlands the number of female GPs increased from 1.961 (25\% of all GPs) in 2000 to 3.532 (40\%) in 2010 [16]. It is important to understand its implications and to study the effects on patient care and the profession [17] and on the working attitude towards selective prevention.

The aim of our study was to compare attitudes and working methods in selective prevention of cardiometabolic diseases before and after the introduction of the guideline. Our research questions therefore were: did the attitudes and working methods of Dutch GPs concerning selective prevention of cardiometabolic diseases change after the introduction of the guideline Prevention Consultation? What are facilitating factors for a GP to implement selective prevention of cardiometabolic diseases? And lastly, is there a relation between GPs' gender and attitudes and working methods in selective prevention of cardiometabolic diseases?

\section{The module cardiometabolic risk of the guideline Prevention Consultation}

This module focuses on adults between the age of 45 and 70 years old. All patients in this age group without diagnosed hypertension, diabetes mellitus type 2, cardiovascular disease, chronic kidney diseases or hypercholesterolemia are invited to fill in an online questionnaire, generated to estimate the risk to develop cardiometabolic diseases. Patients with an increased risk for cardiometabolic diseases based on the questionnaire are invited to visit their GP to complete their risk profile with blood pressure measurements and blood tests for cholesterol and glucose. The patient will receive tailored lifestyle advice and/or start with (preventive) drug treatment if indicated. 
Vos, H.M.M., Delft, D.H.W.J.M. van, Kleijn, M.J.J. de, Nielen, M.M.J., Schellevis, F.G., LagroJanssen, A.L.M. Selective prevention of cardiometabolic diseases in general practice: attitudes and working methods of male and female general practitioners before and after the introdtration of the Prevention Consultation guideline in the Netherlands. Journal of Evaluation in Cliniqglive Practice: 2014, 20(4), 478-485

\section{METHODS}

\section{Participants}

For the cross-sectional survey of Nielen et al. in 2008 a random sample of 1100 GPs was drawn from the national register of practising GPs of NIVEL (The Netherlands Institute for Health Services Research) [2]. In 2013, we conducted a cross-sectional survey among 907 Dutch GPs. NIVEL delivered a gender-stratified random sample of 1500 names and addresses of GPs from their national register of practising GPs, with 50\% of both genders. GP locums were excluded for they are less involved in adopting working methods in general practice. Only one GP per practice was included. Corresponding email addresses were searched via the Internet; 907 email addresses were found.

\section{Questionnaire}

In 2008 a questionnaire was used that contained questions about attitude and working methods of GPs regarding selective prevention of cardiometabolic diseases in general practice [2]. In 2013 we used the same questionnaire, extended with questions about facilitators and barriers in implementing selective prevention and with a question whether the module cardiometabolic risk was actually implemented in their daily practice at the time of the survey. Questions about attitude, working methods, facilitators and barriers were assessed by using a five-grade Likert scale. An active attitude towards preventive working methods was defined as follows: the GP invited patients for preventive measurements and invited patients for preventive measurements who came to the GPs' office for other complaints. Frequency tables were made and answers to the questions were recoded to 'agree' and 'disagree' ('disagree' includes ‘neutral'). In 2008, a paper questionnaire was used, and a reminder was sent after 2 weeks. In 2013, the questionnaire was sent by email in February. Two weeks later also a reminder was sent by email to maximize response.

\section{Analysis}

Statistical analyses were performed with SPSS statistical software 20.0 for Windows (IBM Corp., Armonk, NY, USA). Chi-squared analysis was used to test for bivariate relations between the outcomes cohort $(2008,2013)$, gender, type of practice (single practice, dual practice, group practice, health centre) and age groups ( $<40$ years, 40 49 years, $50-59$ years, $>60$ years). A logistic regression model was used to assess the relation between the cohort, gender, age and type of practice. To explore the moderating effect of gender on the outcome before and after the introduction of the guideline we added an interaction between gender and cohort to the model. Nonsignificant interaction terms were removed from the model; significant interactions were described in the results. A P-value less than 0.05 was considered to be statistically significant.

\section{RESULTS}

\section{GPs' characteristics}

In $200830 \%$ of the random sample of GPs responded $(n=330)$. In 2013, a total of 268 GPs responded and met the inclusion criteria (response rate also 30\%). The characteristics of the respondents in 2008 do not correspond with the characteristics in 2013 regarding age $(\mathrm{P}=0.042)$ and type of practice $(\mathrm{P}=0.004)$. Due to our 
Vos, H.M.M., Delft, D.H.W.J.M. van, Kleijn, M.J.J. de, Nielen, M.M.J., Schellevis, F.G., LagroJanssen, A.L.M. Selective prevention of cardiometabolic diseases in general practice: attitudes and working methods of male and female general practitioners before and after the introdtration of the Prevention Consultation guideline in the Netherlands. Journal of Evaluation in Cliniqglive Practice: 2014, 20(4), 478-485

gender-stratified sample more female GPs responded in 2013 whereas in 2008 more male GPs responded (Table 1).

\section{[TABLE 1]}

\section{Attitudes and working methods in prevention}

In $200878 \%$ of the GPs reported that it is worthwhile to make an effort to detect patients at increased risk for cardiometabolic diseases. In 2013 this percentage dropped to $70 \%$. The multivariate logistic regression showed that the odds ratio (OR) between the 2013 and the 2008 cohort was $0.634(\mathrm{P}=0.026)$. Both in 2008 and in 2013 the respondents considered general practice the appropriate setting to detect cardiometabolic diseases and they considered that preventive measurements must focus on high-risk patients (Table 2).

\section{[TABLE 2]}

In 2013 more GPs reported to actively invite patients for preventive measurements (33\%) compared with $24 \%$ of the GPs in 2008, before the introduction of the cardiometabolic risk module. The OR between the 2013 and the 2008 cohort was $1.743(\mathrm{P}=0.005)$ (Table 3). Most preventive measurements for detecting patients with an increased risk were carried out when patients are known with risk factors, or when patients explicitly asked for it.

\section{[TABLE 3]}

In 2013, 30\% of the GPs carried out the cardiometabolic risk module in their practice. Significantly less GPs in 2013 (79\%) than in 2008 (85\%) indicated that a module cardiometabolic risk is useful. The multivariate logistic regression showed that the OR between the 2013 and the 2008 cohort was $0.599(\mathrm{P}=0.026)$. Less GPs in 2013 indicated that the module may only be carried out by GPs $(\mathrm{OR}=0.285$, $\mathrm{P}=0.000$ ) (Table 4). In 2013 significantly more GPs indicated that a cardiometabolic check may also be performed in other health institutions (Table 5).

\section{[TABLE 4][TABLE 5]}

\section{Gender differences}

Significantly less female GPs than male GPs reported to actively invite patients for preventive measurements $(\mathrm{OR}=0.646, \mathrm{P}=0.044)$ (Table 3). No gender differences were found regarding both strategies of active working methods $(P=0.290)$. No significant moderating effects of gender on the effect of the introduction of the Prevention Consultation guideline were found, except for the opinion ' $\mathrm{A}$ cardiometabolic check may be performed at a diagnostic centre/GPs laboratory' $(\mathrm{P}=0.013)$. Subgroup analyses showed that the OR between the 2013 and the 2008 cohort to agree to this opinion for males $[\mathrm{OR}=1.132$, confidence interval (CI; $0.681-1.882)$ ] is smaller than the OR for females [OR $=2.557$, CI (1.482-4.413)], indicating that the introduction of the Prevention Consultation guideline changed female GPs' opinion more towards a diagnostic centre/GPs laboratory being a suitable place to perform a cardiometabolic check. 
Vos, H.M.M., Delft, D.H.W.J.M. van, Kleijn, M.J.J. de, Nielen, M.M.J., Schellevis, F.G., LagroJanssen, A.L.M. Selective prevention of cardiometabolic diseases in general practice: attitudes and working methods of male and female general practitioners before and after the introdtration of the Prevention Consultation guideline in the Netherlands. Journal of Evaluation in Cliniqglive Practice: 2014, 20(4), 478-485

\section{Facilitators of selective prevention of cardiometabolic diseases}

Both financial compensation for the extra time and effort spent (90\%) and financial support to offer a practice nurse more working time (92\%) were mentioned as facilitating factors to spend more time on selective prevention of cardiometabolic diseases. Slightly even more GPs (95\%) mentioned scientific evidence about the effectiveness of selective prevention as a facilitating factor. Seventy-three per cent would be inclined to carry out selective prevention if it will cost them little extra effort.

\section{DISCUSSION}

\section{Main results and interpretation}

We aimed to study how attitudes and working methods of Dutch GPs in selective prevention of cardiometabolic diseases changed after the introduction of the module cardiometabolic risk of the guideline Prevention Consultation in 2011. Although both in 2008 and in 2013 the majority of the GPs reported it is worthwhile to detect patients at increased risk for cardiometabolic diseases, this number significantly decreased and less GPs indicated that a module cardiometabolic risk is useful after the introduction of the module. We found that more GPs actively approached patients for preventive actions of cardiometabolic diseases after the introduction of the module cardiometabolic risk. We cannot conclude that the introduction of the module was the only cause of this change in working methods, because this change can as well be caused by other factors than the introduction of the module cardiometabolic risk, for example, the increased availability of practice nurses in general practice in the Netherlands, and the increasing interest in prevention in politics and society. Moreover, even though an active approach of patients with an unknown risk for cardiometabolic diseases increased, preventive measurements are both in 2008 and in 2013 most frequently performed when patients explicitly ask for it or when patients already have known risk factors for cardiometabolic diseases. Although in 2013 the majority of the GPs still are positive about the module cardiometabolic risk, only $30 \%$ of the respondents have fully implemented this module in their practice. This relatively low number could be explained by the extra workload and costs this module brings along with, but also by the question whether scientific evidence of the effectiveness of the module is sufficient, especially as we found that less GPs indicated that a module cardiometabolic risk is useful after the introduction of the module. An explanation for this decrease could be that in 2008 the expectations were high; in 2013 the module was available, and the expectations were not entirely fulfilled. Further research of the effectiveness of the module cardiometabolic risk in preventing cardiometabolic diseases in general practice is therefore necessary. It is particularly important that sufficient financial support will come available for the implementation of selective prevention.

Our findings are largely consistent with findings from our previous research in which we concluded that insecurity about reimbursement and lack of scientific evidence were the main barriers for the implementation of prevention programmes in general practice [10]. Nevertheless, in that study we hypothesized that the ethical view of GPs that everyone should have the same right to obtain preventive care gradually takes over the inclination to hold on to evidence-based prevention. Heavy workload, 
Vos, H.M.M., Delft, D.H.W.J.M. van, Kleijn, M.J.J. de, Nielen, M.M.J., Schellevis, F.G., LagroJanssen, A.L.M. Selective prevention of cardiometabolic diseases in general practice: attitudes and working methods of male and female general practitioners before and after the introdtion 7 of the Prevention Consultation guideline in the Netherlands. Journal of Evaluation in Cliniqglive Practice: 2014, 20(4), 478-485

lack of time and lack of remuneration were also mentioned in other studies as barriers for the implementation of prevention in general practice [18-20]. GPs consider general practice as the most appropriate setting to carry out preventive measurements. Remarkable, however, is the finding that GPs nowadays, in contrast to 2008, more often report that a cardiometabolic check may also be performed in other health institutions. This can be explained by the more firm position of general practice nowadays [21] and the increasing workload perceived by GPs [18]. We found that more male GPs actively invite patients to visit the practice for preventive measurements, compared with female GPs. We hypothesized that this can be explained by broader focus on finances [22] and organization by male GPs that stimulates them to implement prevention programmes in which they actively invite patients. Female GPs have longer patient visits [23] and compared with male GPs and female GPs are more active in preventive counselling but equal in preventive screening [14]. Less female GPs actively invited patients for preventive measurements in our study. The female GPs seem to compensate for actively inviting patients for prevention with preventive measurements in patients who visit the general practice for other complaints, probably enabled by the longer visits [22-24], for no gender differences were found comparing both strategies of active working methods together.

\section{Strength and limitations}

The strength of our cross-sectional study is the availability of a representative population of GPs before and after the introduction of the module cardiometabolic risk. The characteristics of our respondents in 2013 mainly correspond with characteristics of GPs in the Netherlands [15], except for gender. This difference is deliberately caused by our gender-stratified sample. The characteristics of our respondents in 2013 do not correspond with the characteristics of respondents in 2008 regarding age, gender and type of practice. We therefore adjusted for age, gender and type of practice in the comparison of the studies using multivariable logistic regressions.

Both in 2008 [2] and in 2013, the response to the questionnaire was only 30\%. We know from previous research that response rates among GPs often are low [25,26]. Low response rates are not problematic as long as the study population is representative for the entire target population. In our study the study population is representative, as is shown in Table 1.

It is possible that GPs with more positive attitudes and working methods towards active prevention strategies in cardiometabolic diseases and with more interest in selective prevention responded in 2013. This can lead to selection bias. However, we assume that both in 2013 and in 2008 the GPs who responded showed as well more positive attitudes and working methods compared with the non-responders.

\section{CONCLUSION}

Our main conclusion is that in 2013 GPs report more active working methods towards selective prevention of cardiometabolic diseases, but only 30\% fully implemented the module cardiometabolic risk in their practice. In 2013, less GPs considered the module cardiometabolic risk as useful as part of the Prevention Consultation. They are more willing to delegate preventive actions to other 
Vos, H.M.M., Delft, D.H.W.J.M. van, Kleijn, M.J.J. de, Nielen, M.M.J., Schellevis, F.G., LagroJanssen, A.L.M. Selective prevention of cardiometabolic diseases in general practice: attitudes and working methods of male and female general practitioners before and after the introdtration of the Prevention Consultation guideline in the Netherlands. Journal of Evaluation in Cliniqglive Practice: 2014, 20(4), 478-485

stakeholders compared with 2008. GPs consider financial compensation for the extra time and effort spent and evidence about the (cost-)effectiveness of selective prevention of cardiometabolic diseases as important facilitators for implementation. More male GPs than female GPs actively invite patients to visit the practice for preventive measurements. No gender differences were found comparing both strategies of active working methods together.

Further research is necessary to study whether the module cardiometabolic risk will lead to a decrease of the number of patients with cardiometabolic diseases, whether the module cardiometabolic risk of the Prevention Consultation guideline in particular is useful, whether selective prevention of cardiometabolic diseases in general practice is cost-effective and whether GP gender is a factor to take into account when implementing a prevention programme. Political choices have to be made in order to financially facilitate selective prevention in general practice.

\section{CONFLICT OF INTEREST}

The authors declare no conflict of interest.

\section{ACKNOWLEDGEMENT}

A significant contribution to statistical analysis and interpretation of data was made by Hans H. Bor, BSc Math, Department of Primary and Community Care, Gender and Women's Health, Radboud UMC, The Netherlands.

\section{REFERENCES}

1 Dekker, J. M., Alssema, M., Janssen, P. G. H., et al. (2011) NHG guideline the Prevention Consultation module cardio-metabolic risk [Article in Dutch]. Huisarts en Wetenschap, 54, 138-155.

2 Nielen, M. M., Assendelft, W. J., Drenthen, A. J., Van den Hombergh, P., Van Dis, I. \& Schellevis, F. G. (2010) Primary prevention of cardio-metabolic diseases in general practice: a Dutch survey of attitudes and working methods of general practitioners. The European Journal of General Practice, 16, 139-142.

3 World Health Organization (2008) The Global Burden of Disease: 2004 Update. Geneva: WHO Press.

4 Lozano, R., Naghavi, M., Foreman, K., et al. (2010) Global and regional mortality from 235 causes of death for 20 age groups in 1990 and 2010: a systematic analysis for the Global Burden of Disease Study 2010. Lancet, 380, 2095-2128.

5 McAvoy, B. R., Kaner, E. F., Lock, C. A., Heather, N. \& Gilvarry, E. (1999) Our healthier nation: are general practioners willing and able to deliver? A survey of attitudes to and involvement in health promotion and lifestyle counseling. The British Journal of General Practice, 49, 187-190.

6 Smits, F. T. M., Mohrs, J. J., Beem, E. E., Bindels, P. J. E. \& Van Weert, H. C. P. H. (2008) Defining frequent attendance in general practice. BMC Family Practice, 9, 21.

7 Spronk, I., Ursum, J., Davids, R., Stirbu, I., Nielen, M. M. J., Korevaar, J. C., \& Verheij, R. A. (2013) Huisarts - Aantal patiënten met minimaal 1 contact met de huisartsenpraktijk [General practitioner - number of patients with at least one contact per year at a general practice]. NIVEL Zorgregistraties eerste lijn. Available at: http://www.nivel.nl/node/3439 (last accessed 7 May 2014).

8 Hulscher, M. E., Van Drenth, B. B., Mokkink, H. G., Van der Wouden, J. C. \& Grol, R. P. (1997) Barriers to preventive care in general practice: the role of organizational and attitudinal factors. The British Journal of General Practice, 47, 711-714. 
Vos, H.M.M., Delft, D.H.W.J.M. van, Kleijn, M.J.J. de, Nielen, M.M.J., Schellevis, F.G., LagroJanssen, A.L.M. Selective prevention of cardiometabolic diseases in general practice: attitudes and working methods of male and female general practitioners before and after the introdtration of the Prevention Consultation guideline in the Netherlands. Journal of Evaluation in Cliniqglive Practice: 2014, 20(4), 478-485

9 Assendelft, W. J., Nielen, M. M., Hettinga, D. M., Van der Meer, V., Van Vliet, M., Drenthen, A. J., Schellevis, F. G. \& Van Oosterhout, M. J. (2012) Bridging the gap between public health and primary care in prevention of cardiometabolic diseases; background of and experiences with the Prevention Consultation in The Netherlands. Family Practice, 29 (Suppl. 1), i126-i131.

10 Vos, H. M. M., Adan, I. M. A., Schellevis, F. G. \& Lagro-Janssen, A. L. M. (2013) Prevention in primary care: facilitators and barriers to transform prevention from a random coincidence to a systematic approach. Journal of Evaluation in Clinical Practice. doi: 10.1111/jep.12108

11 Van der Meer, V., Nielen, M. M., Drenthen, A. J., Van Vliet, M., Assendelft, W. J. \& Schellevis, F. G. (2013) Cardio-metabolic prevention consultation in the Netherlands: screening uptake and detection of cardio-metabolic risk factors and diseases - a pilot study. BMC Family Practice, 14, 29.

12 Levinson, W. \& Lurie, N. (2004) When most doctors are women: what lies ahead? Annals of Internal Medicine, 141, 471-474.

13 Lagro-Janssen, A. L. (2008) Medicine is not gender-neutral: influence of physician sex on medical care [Article in Dutch]. Nederlands Tijdschrift Voor Geneeskunde, 152, 11411145.

14 Flocke, S. A. \& Gilchrist, V. (2005) Physician and patient gender concordance and the delivery of comprehensive clinical preventive services. Medical Care, 43, 486-492.

15 Henderson, J. T. \& Weisman, C. S. (2001) Physician gender effects on preventive screening and counseling: an analysis of male and female patients' health care experiences. Medical Care, 39, 1281-1292.

16 Hingstman, L. \& Kenens, R. J. (2010) NIVEL. Cijfers uit de registratie van huisartsen. Peiling 2010 Available at: http://www.nivel.nl/sites/default/files/bestanden/cijfers-uit-deregistratie-van-huisartsen-peiling-jan-2010.pdf (last accessed 25 October 2013).

17 Biringer, A. \& Carroll, J. C. (2012) What does the feminization of family medicine mean? Canadian Medical Association Journal, 184, 1752.

18 Mcllfatrick, S., Keeney, S., McKenna, H., McCarley, N. \& McElwee, G. (2013) Investigating the role of the general practitioner in cancer prevention: a mixed methods study. BMC Family Practice, 14, 58.

19 Brotons, C., Björkelund, C., Bulc, M., et al. (2005) Prevention and health promotion in clinical practice: the views of general practitioners in Europe. Preventive Medicine, 40, 595-601.

20 WHO Collaborative Group (1998) WHO Phase III Collaborative Study on Implementing and Supporting Early Intervention Strategies in Primary Health Care. Report on Strand I: General Practitioners' Current Practices and Perceptions of Preventive Medicine and Early Intervention for Hazardous Alcohol Use. A 16 Country Study. Copenhagen: WHO.

21 Kroneman, M., Meeus, P., Kringos, D. S., Groot, W. \& Van der Zee, J. (2013) International developments in revenues and incomes of general practitioners from 2000 to 2010. BMC Health Services Research, 13, 436.

22 Weeks, W. B., Paraponaris, A. \& Ventelou, B. (2013) Sex-based differences in income and response to proposed financial incentives among general practitioners in France. Health Policy, 113, 199-205.

23 Bensing, J. M., Van den Brink-Muinen, A. \& De Bakker, D. H. (1993) Gender differences in practice style: a Dutch study of general practitioners. Medical Care, 31, 219-229.

24 Roter, D. L. \& Hall, J. A. (2004) Physician gender and patient-centered communication: a critical review of empirical research. Annual Review of Public Health, 25, 497-519.

25 Shillinglaw, B., Viera, A. J., Edwards, T., Simpson, R. \& Sheridan, S. L. (2012) Use of global coronary heart disease risk assessment in practice: a cross-sectional survey of a sample of U.S. physicians. BMC Health Services Research, 12, 20.

26 McAvoy, B. R. \& Kaner, E. F. (1996) General practice postal surveys: a questionnaire too far? British Medical Journal, 313, 732-734. 
Vos, H.M.M., Delft, D.H.W.J.M. van, Kleijn, M.J.J. de, Nielen, M.M.J., Schellevis, F.G., Lagro-

Janssen, A.L.M. Selective prevention of cardiometabolic diseases in general practice: attitudes and working methods of male and female general practitioners before and after the introdtration

of the Prevention Consultation guideline in the Netherlands. Journal of Evaluation in Cliniqglive

Practice: 2014, 20(4), 478-485

\section{TABLES AND FIGURES}

Table 1. Characteristics of the study population in 2008 and 2013

\begin{tabular}{|c|c|c|c|c|}
\hline & \begin{tabular}{|c} 
Respondents 2008, \\
$N(\%)$
\end{tabular} & $\begin{array}{c}\text { Respondents 2013, } \\
N(\%)\end{array}$ & $\mid \begin{array}{c}P- \\
\text { value }\end{array}$ & $\begin{array}{c}\text { All GPs in the Netherlands in } \\
\% \text { a, } n=8.884\end{array}$ \\
\hline Age category & $N=330$ & $N=247$ & \multirow{5}{*}{0.042} & \\
\hline$\angle 40$ years old & $71(22)$ & $46(19)$ & & 20 \\
\hline $\begin{array}{l}40-49 \text { years } \\
\text { old }\end{array}$ & 88 (27) & 84 (34) & & 31 \\
\hline $\begin{array}{l}50-59 \text { years } \\
\text { old }\end{array}$ & 147 (45) & 89 (36) & & 38 \\
\hline $\begin{array}{l}60 \text { years and } \\
\text { older }\end{array}$ & $24(7)$ & |28 (11) & & 11 \\
\hline Gender $^{\mathrm{b}}$ & $N=330$ & $N=247$ & \multirow{3}{*}{0.000} & \\
\hline Male & $202(61)$ & $105(43)$ & & 59 \\
\hline Female & $128(39)$ & $142(58)$ & & 41 \\
\hline $\begin{array}{l}\text { Type of } \\
\text { practice }\end{array}$ & $N=328$ & $N=247$ & \multirow{5}{*}{0.004} & \\
\hline Single handed & $101(31)$ & $55(22)$ & & 18 \\
\hline Duo practice & $112(34)$ & $69(28)$ & & 28 \\
\hline $\begin{array}{l}\text { Group } \\
\text { practice }\end{array}$ & $79(24)$ & |88 (36) & & \multirow[t]{2}{*}{54} \\
\hline Health centre & $36(11)$ & $35(14)$ & & \\
\hline
\end{tabular}

${ }^{a}$ NIVEL (The Netherlands Institute for Health Services Research), data from the register of general practitioners (GPs), 2011.

${ }^{\mathrm{b}}$ Stratified sample in 2013. 
Vos, H.M.M., Delft, D.H.W.J.M. van, Kleijn, M.J.J. de, Nielen, M.M.J., Schellevis, F.G., LagroJanssen, A.L.M. Selective prevention of cardiometabolic diseases in general practice: attitudes and working methods of male and female general practitioners before and after the introdtiction of the Prevention Consultation guideline in the Netherlands. Journal of Evaluation in Cliniqalive Practice: 2014, 20(4), 478-485

Table 2. GPs' opinions about selective prevention of cardiometabolic disease

\begin{tabular}{|c|c|c|c|c|c|c|c|c|c|c|c|c|}
\hline & \multicolumn{3}{|c|}{\begin{tabular}{|c|} 
It is worthwhile to \\
make an effort to \\
detect patients at \\
increased risk for \\
cardiometabolic \\
diseases following \\
the current \\
guidelines $(n=572)$
\end{tabular}} & \multicolumn{3}{|c|}{\begin{tabular}{|} 
Early detection of \\
patients at increased \\
risk for \\
cardiometabolic \\
diseases improves \\
survival and quality \\
of life $(n=572)$
\end{tabular}} & \multicolumn{3}{|c|}{$\begin{array}{l}\text { Early detection of } \\
\text { patients at } \\
\text { increased risk for } \\
\text { cardiometabolic } \\
\text { disease will be cost- } \\
\text { effective }(n=571)\end{array}$} & \multicolumn{3}{|c|}{$\begin{array}{c}\text { General practice is } \\
\text { the most } \\
\text { appropriate setting } \\
\text { to detect } \\
\text { cardiometabolic } \\
\text { disease }(n=571)\end{array}$} \\
\hline & OR & $\begin{array}{c}95 \% \\
\text { CI }\end{array}$ & $\boldsymbol{P}$ & OR & $\begin{array}{c}95 \% \\
\text { CI }\end{array}$ & $\boldsymbol{P}$ & OR & $\begin{array}{c}95 \% \\
\text { CI }\end{array}$ & $\boldsymbol{P}$ & OR & $\begin{array}{c}95 \% \\
\text { CI }\end{array}$ & $\boldsymbol{P}$ \\
\hline \begin{tabular}{|l|} 
Cohort \\
$(2013$, ref \\
$2008)$
\end{tabular} & $\mid 0.634$ & $\mid \begin{array}{l}0.425- \\
0.946\end{array}$ & 0.026 & 0.712 & $\begin{array}{l}0.484- \\
1.048\end{array}$ & $\mid 0.085$ & 0.869 & $\begin{array}{l}0.611- \\
1.234\end{array}$ & 0.432 & 0.726 & $\mid \begin{array}{l}0.378- \\
1.392\end{array}$ & 0.334 \\
\hline \begin{tabular}{|l|}
$\begin{array}{l}\text { Gender } \\
\text { (female, } \\
\text { ref male) }\end{array}$ \\
\end{tabular} & ||0.882 & $\mid \begin{array}{l}0.569- \\
1.368\end{array}$ & 0.576 & 0.716 & $\begin{array}{l}0.468- \\
1.096\end{array}$ & 0.124 & 0.801 & $\begin{array}{l}0.544- \\
1.179\end{array}$ & 0.261 & 0.473 & $\mid \begin{array}{l}0.227- \\
0.984\end{array}$ & 0.045 \\
\hline Age & & & 0.011 & & & 0.024 & & & 0.839 & & & 0.565 \\
\hline $\begin{array}{l}<40 \text { years } \\
\text { old }\end{array}$ & ref & & & ref & & & ref & & & ref & & \\
\hline $\begin{array}{l}40- \\
49 \text { years } \\
\text { old }\end{array}$ & $\mid 0.611$ & $\mid \begin{array}{l}0.326- \\
1.145\end{array}$ & 0.124 & 0.452 & $\begin{array}{l}0.251- \\
0.811\end{array}$ & $\mid 0.008$ & 1.000 & $\begin{array}{l}0.612- \\
1.634\end{array}$ & 0.999 & 0.554 & $\mid \begin{array}{l}0.212- \\
1.451\end{array}$ & 0.230 \\
\hline $\begin{array}{l}50- \\
59 \text { years } \\
\text { old }\end{array}$ & $\mid 0.370$ & $\mid \begin{array}{l}0.200- \\
0.684\end{array}$ & 0.001 & 0.431 & $\begin{array}{l}0.239- \\
0.778\end{array}$ & $\mid 0.005$ & 0.871 & $\begin{array}{l}0.532- \\
1.426\end{array}$ & 0.583 & 0.522 & $\mid \begin{array}{l}0.198- \\
1.379\end{array}$ & 0.190 \\
\hline $\begin{array}{l}>60 \text { years } \\
\text { old }\end{array}$ & $\mid 0.494$ & $\begin{array}{l}0.212- \\
1.151\end{array}$ & 0.102 & 0.638 & $\begin{array}{l}0.273- \\
1.495\end{array}$ & || 0.301 & 0.774 & $0.377-$ & 0.485 & 0.733 & \begin{tabular}{|l}
$0.166-$ \\
3.245
\end{tabular} & 0.683 \\
\hline $\begin{array}{l}\text { Type of } \\
\text { practice }\end{array}$ & & & 0.287 & & & || 0.877 & & & 0.348 & & & 0.146 \\
\hline $\begin{array}{l}\text { Single } \\
\text { handed }\end{array}$ & ref & & & ref & & & ref & & & ref & & \\
\hline $\begin{array}{l}\text { Duo } \\
\text { practice }\end{array}$ & || 0.729 & $\begin{array}{l}0.438- \\
1.213\end{array}$ & 0.223 & 1.187 & $\begin{array}{l}0.720- \\
1.958 \\
\end{array}$ & ||0.502 & 0.840 & \begin{tabular}{|l}
$0.537-$ \\
1.315 \\
\end{tabular} & 0.446 & 2.060 & $\begin{array}{l}0.905- \\
4.688\end{array}$ & 0.085 \\
\hline $\begin{array}{l}\text { Group } \\
\text { practice }\end{array}$ & ||1.182 & $\begin{array}{l}0.688- \\
2.032\end{array}$ & 0.544 & 1.216 & $\begin{array}{l}0.732- \\
2.019 \\
\end{array}$ & || 0.450 & 1.011 & $\begin{array}{l}0.643- \\
1.589 \\
\end{array}$ & 0.962 & 2.553 & $\begin{array}{l}1.060- \\
6.146 \\
\end{array}$ & 0.037 \\
\hline \begin{tabular}{|l}
$\begin{array}{l}\text { Health } \\
\text { centre }\end{array}$ \\
\end{tabular} & ||0.916 & $\begin{array}{l}0.473- \\
1.772 \\
\end{array}$ & 0.793 & 1.172 & \begin{tabular}{|l}
$0.617-$ \\
2.228 \\
\end{tabular} & $\mid 0.627$ & 0.620 & $\begin{array}{l}0.341- \\
1.125 \\
\end{array}$ & 0.116 & 1.354 & $\begin{array}{l}0.514- \\
3.569\end{array}$ & 0.539 \\
\hline
\end{tabular}


Vos, H.M.M., Delft, D.H.W.J.M. van, Kleijn, M.J.J. de, Nielen, M.M.J., Schellevis, F.G., LagroJanssen, A.L.M. Selective prevention of cardiometabolic diseases in general practice: attitudes and working methods of male and female general practitioners before and after the introdtration of the Prevention Consultation guideline in the Netherlands. Journal of Evaluation in Cliniqalive

Practice: 2014, 20(4), 478-485

\begin{tabular}{|c|c|c|c|c|c|c|c|c|c|}
\hline & \multicolumn{3}{|c|}{$\begin{array}{c}\text { Good lifestyle advise can } \\
\text { only be given when there } \\
\text { is enough time during the } \\
\text { consultation }(n=572)\end{array}$} & \multicolumn{3}{|c|}{$\begin{array}{c}\text { Preventive activities are } \\
\text { exceptionally suited for a } \\
\text { practice nurse to carry } \\
\text { out }(n=572)\end{array}$} & \multicolumn{3}{|c|}{$\begin{array}{c}\text { Activities in detecting } \\
\text { patients with increased risk } \\
\text { for cardiometabolic diseases } \\
\text { must focus on high-risk } \\
\text { patients }(n=572)\end{array}$} \\
\hline & OR & 95\% CI & $P$ & OR & 95\% CI & $\bar{P}$ & 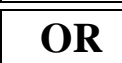 & 95\% CI & $\bar{P}$ \\
\hline \begin{tabular}{|l} 
Cohort \\
$(2013$, ref \\
$2008)$ \\
\end{tabular} & 0.740 & $\begin{array}{l}0.443- \\
1.237\end{array}$ & 0.251 & 1.026 & $\begin{array}{l}0.615- \\
1.712\end{array}$ & $\mid 0.922$ & 1.246 & $\mid 0.718-2.162$ & 0.434 \\
\hline $\begin{array}{l}\text { Gender } \\
\text { (female, } \\
\text { ref male) }\end{array}$ & 0.729 & $\begin{array}{l}0.414- \\
1.283\end{array}$ & 0.273 & 0.628 & $\begin{array}{l}0.355- \\
1.110\end{array}$ & $\mid 0.109$ & 1.407 & $\mid 0.767-2.581$ & 0.270 \\
\hline Age & & & 0.621 & & & 0.137 & & & 0.269 \\
\hline $\begin{array}{l}<40 \text { years } \\
\text { old }\end{array}$ & ref & & & ref & & & ref & & \\
\hline $\begin{array}{l}40- \\
49 \text { years } \\
\text { old }\end{array}$ & 1.348 & $\mid \begin{array}{l}0.657- \\
2.765\end{array}$ & 0.415 & 1.046 & $\begin{array}{l}0.490- \\
2.229\end{array}$ & $\mid 0.908$ & 1.632 & $0.778-3.424$ & 0.195 \\
\hline $\begin{array}{l}50- \\
59 \text { years } \\
\text { old }\end{array}$ & 0.927 & $\begin{array}{l}0.465- \\
1.848\end{array}$ & 0.830 & 0.684 & $\begin{array}{l}0.331- \\
1.411\end{array}$ & $\mid 0.303$ & 1.435 & $\mid 0.700-2.942$ & 0.324 \\
\hline $\begin{array}{l}>60 \text { years } \\
\text { old }\end{array}$ & 1.384 & \begin{tabular}{|l}
$0.451-$ \\
4.245 \\
\end{tabular} & 0.570 & 0.391 & \begin{tabular}{|l}
$0.152-$ \\
1.015 \\
\end{tabular} & $\mid 0.054$ & 3.503 & $\begin{array}{l}0.921- \\
13.330 \\
\end{array}$ & 0.066 \\
\hline $\begin{array}{l}\text { Type of } \\
\text { practice }\end{array}$ & & & 0.705 & & & 0.477 & & & 0.194 \\
\hline \begin{tabular}{|l} 
Single \\
handed
\end{tabular} & ref & & & ref & & & ref & & \\
\hline \begin{tabular}{|l} 
Duo \\
practice
\end{tabular} & 1.002 & $\begin{array}{l}0.499- \\
2.010 \\
\end{array}$ & 0.996 & 1.022 & \begin{tabular}{|l}
$0.549-$ \\
1.901 \\
\end{tabular} & 0.946 & 1.623 & ||0.834-3.159 & 0.154 \\
\hline \begin{tabular}{|l} 
Group \\
practice
\end{tabular} & 0.841 & \begin{tabular}{|l}
$0.424-$ \\
1.666 \\
\end{tabular} & 0.619 & 1.575 & \begin{tabular}{|l|}
$0.792-$ \\
3.131 \\
\end{tabular} & || 0.195 & 1.332 & $\mid 0.695-2.554$ & 0.387 \\
\hline \begin{tabular}{|l}
$\begin{array}{l}\text { Health } \\
\text { centre }\end{array}$ \\
\end{tabular} & 0.659 & \begin{tabular}{|l}
$0.292-$ \\
1.485 \\
\end{tabular} & 0.314 & 1.446 & \begin{tabular}{|l|}
$0.605-$ \\
3.459 \\
\end{tabular} & $\mid 0.407$ & 3.017 & $\mid 1.000-9.105$ & 0.050 \\
\hline
\end{tabular}

A comparison before and after the introduction of the Prevention Consultation guideline, controlling for gender differences, age differences and differences in type of practice, a multivariable logistic regression. Italicized $P$-values are statistically significant.

CI, confidence interval; GPs, general practitioners; OR, odds ratio. 
Vos, H.M.M., Delft, D.H.W.J.M. van, Kleijn, M.J.J. de, Nielen, M.M.J., Schellevis, F.G., LagroJanssen, A.L.M. Selective prevention of cardiometabolic diseases in general practice: attitudes and working methods of male and female general practitioners before and after the introdtiction of the Prevention Consultation guideline in the Netherlands. Journal of Evaluation in Cliniqalive Practice: 2014, 20(4), 478-485

Table 3. GPs' working methods to detect patients with an increased risk for cardiometabolic diseases

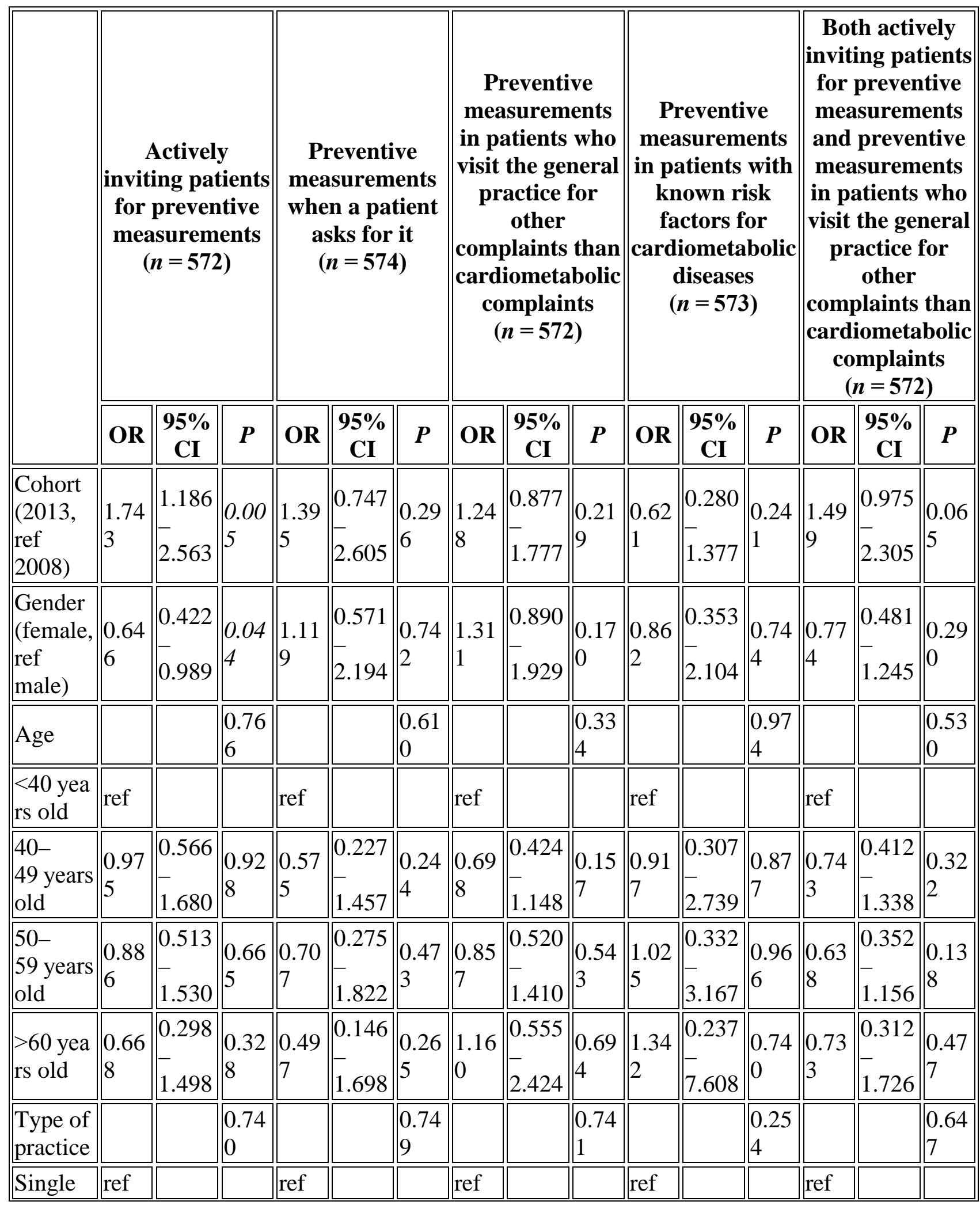




\begin{tabular}{|c|c|c|c|c|c|c|c|c|c|c|c|c|c|c|c|}
\hline & \multicolumn{3}{|c|}{$\begin{array}{c}\text { Actively } \\
\text { inviting patients } \\
\text { for preventive } \\
\text { measurements } \\
\quad(n=572)\end{array}$} & \multicolumn{3}{|c|}{$\begin{array}{c}\text { Preventive } \\
\text { measurements } \\
\text { when a patient } \\
\text { asks for it } \\
(n=574)\end{array}$} & \multicolumn{3}{|c|}{\begin{tabular}{||c} 
Preventive \\
measurements \\
in patients who \\
visit the general \\
practice for \\
other \\
complaints than \\
cardiometabolic \\
complaints \\
$(n=572)$
\end{tabular}} & \multicolumn{3}{|c|}{\begin{tabular}{||c} 
Preventive \\
measurements \\
in patients with \\
known risk \\
factors for \\
cardiometabolic \\
diseases \\
$(n=573)$
\end{tabular}} & \multicolumn{3}{|c|}{$\begin{array}{l}\text { Both actively } \\
\text { inviting patients } \\
\text { for preventive } \\
\text { measurements } \\
\text { and preventive } \\
\text { measurements } \\
\text { in patients who } \\
\text { visit the general } \\
\text { practice for } \\
\text { other } \\
\text { complaints than } \\
\text { cardiometabolic } \\
\text { complaints } \\
(n=572)\end{array}$} \\
\hline & OR & $\begin{array}{c}95 \% \\
\text { CI }\end{array}$ & $\boldsymbol{P}$ & OR & \begin{tabular}{|c|}
$95 \%$ \\
CI \\
\end{tabular} & $\boldsymbol{P}$ & OR & \begin{tabular}{|c|}
$95 \%$ \\
CI \\
\end{tabular} & $\boldsymbol{P}$ & OR & \begin{tabular}{|c|}
$95 \%$ \\
CI \\
\end{tabular} & $\boldsymbol{P}$ & OR & $\begin{array}{c}95 \% \\
\text { CI }\end{array}$ & $\boldsymbol{P}$ \\
\hline \multicolumn{16}{|l|}{ handed } \\
\hline $\mid \begin{array}{l}\text { Duo } \\
\text { practice }\end{array}$ & $\begin{array}{l}1.00 \\
0\end{array}$ & \begin{tabular}{|l}
0.603 \\
- \\
1.659 \\
\end{tabular} & $\begin{array}{l}0.99 \\
9\end{array}$ & $\begin{array}{l}0.87 \\
4\end{array}$ & \begin{tabular}{|l}
0.417 \\
- \\
1.831 \\
\end{tabular} & $\begin{array}{l}0.72 \\
1\end{array}$ & $\begin{array}{l}0.98 \\
8\end{array}$ & $\begin{array}{l}0.630 \\
- \\
1.548\end{array}$ & $\begin{array}{l}0.95 \\
7\end{array}$ & $\mid \begin{array}{l}2.05 \\
1\end{array}$ & \begin{tabular}{|l}
0.752 \\
- \\
5.593 \\
\end{tabular} & $\mid \begin{array}{l}0.16 \\
0\end{array}$ & $\mid \begin{array}{l}0.86 \\
6\end{array}$ & \begin{tabular}{|l|}
0.489 \\
- \\
1.534 \\
\end{tabular} & $\mid \begin{array}{l}0.62 \\
3\end{array}$ \\
\hline $\mid \begin{array}{l}\text { Group } \\
\text { practice }\end{array}$ & $\begin{array}{l}1.17 \\
8\end{array}$ & \begin{tabular}{|l}
0.715 \\
- \\
1.941 \\
\end{tabular} & $\begin{array}{l}0.52 \\
1\end{array}$ & $\begin{array}{l}1.27 \\
3\end{array}$ & \begin{tabular}{|l}
0.565 \\
- \\
2.870 \\
\end{tabular} & $\begin{array}{l}0.56 \\
0\end{array}$ & $\begin{array}{l}1.20 \\
4\end{array}$ & $\begin{array}{l}0.761 \\
- \\
1.905\end{array}$ & $\begin{array}{l}0.42 \\
9\end{array}$ & $\mid \begin{array}{l}1.54 \\
6\end{array}$ & \begin{tabular}{|l}
0.606 \\
- \\
3.942 \\
\end{tabular} & $\mid \begin{array}{l}0.36 \\
2\end{array}$ & $\begin{array}{l}1.12 \\
6\end{array}$ & \begin{tabular}{|l|}
0.648 \\
-1.958 \\
\end{tabular} & \begin{tabular}{|l|}
0.67 \\
3
\end{tabular} \\
\hline $\begin{array}{l}\text { Health } \\
\text { centre }\end{array}$ & $\begin{array}{l}1.33 \\
0\end{array}$ & $\mid \begin{array}{l}0.712 \\
- \\
2.484\end{array}$ & $\begin{array}{l}0.37 \\
1\end{array}$ & $\begin{array}{l}1.31 \\
7\end{array}$ & $\mid \begin{array}{l}0.453 \\
- \\
3.826\end{array}$ & $\begin{array}{l}0.61 \\
3\end{array}$ & $\begin{array}{l}0.9 \\
7\end{array}$ & $\mid$\begin{tabular}{l||}
0.515 \\
- \\
1.633
\end{tabular} & $\begin{array}{l}0.76 \\
9\end{array}$ & $\mid \begin{array}{l}6.08 \\
9\end{array}$ & \begin{tabular}{|l}
0.759 \\
- \\
48.86 \\
4
\end{tabular} & $\mid \begin{array}{l}0.08 \\
9\end{array}$ & $\mid \begin{array}{l}1.29 \\
9\end{array}$ & $\left|\begin{array}{l}0.654 \\
- \\
2.578\end{array}\right|$ & 0.45 \\
\hline
\end{tabular}

A comparison before and after the introduction of the Prevention Consultation guideline, controlling for gender differences, age differences and differences in type of practice, a multivariable logistic regression. Italicized $P$-values are statistically significant.

CI, confidence interval; GPs, general practitioners; OR, odds ratio. 
Vos, H.M.M., Delft, D.H.W.J.M. van, Kleijn, M.J.J. de, Nielen, M.M.J., Schellevis, F.G., LagroJanssen, A.L.M. Selective prevention of cardiometabolic diseases in general practice: attitudes and working methods of male and female general practitioners before and after the introdtretion of the Prevention Consultation guideline in the Netherlands. Journal of Evaluation in Cliniqglive

Practice: 2014, 20(4), 478-485

Table 4. GPs' opinions about the module cardiometabolic risk

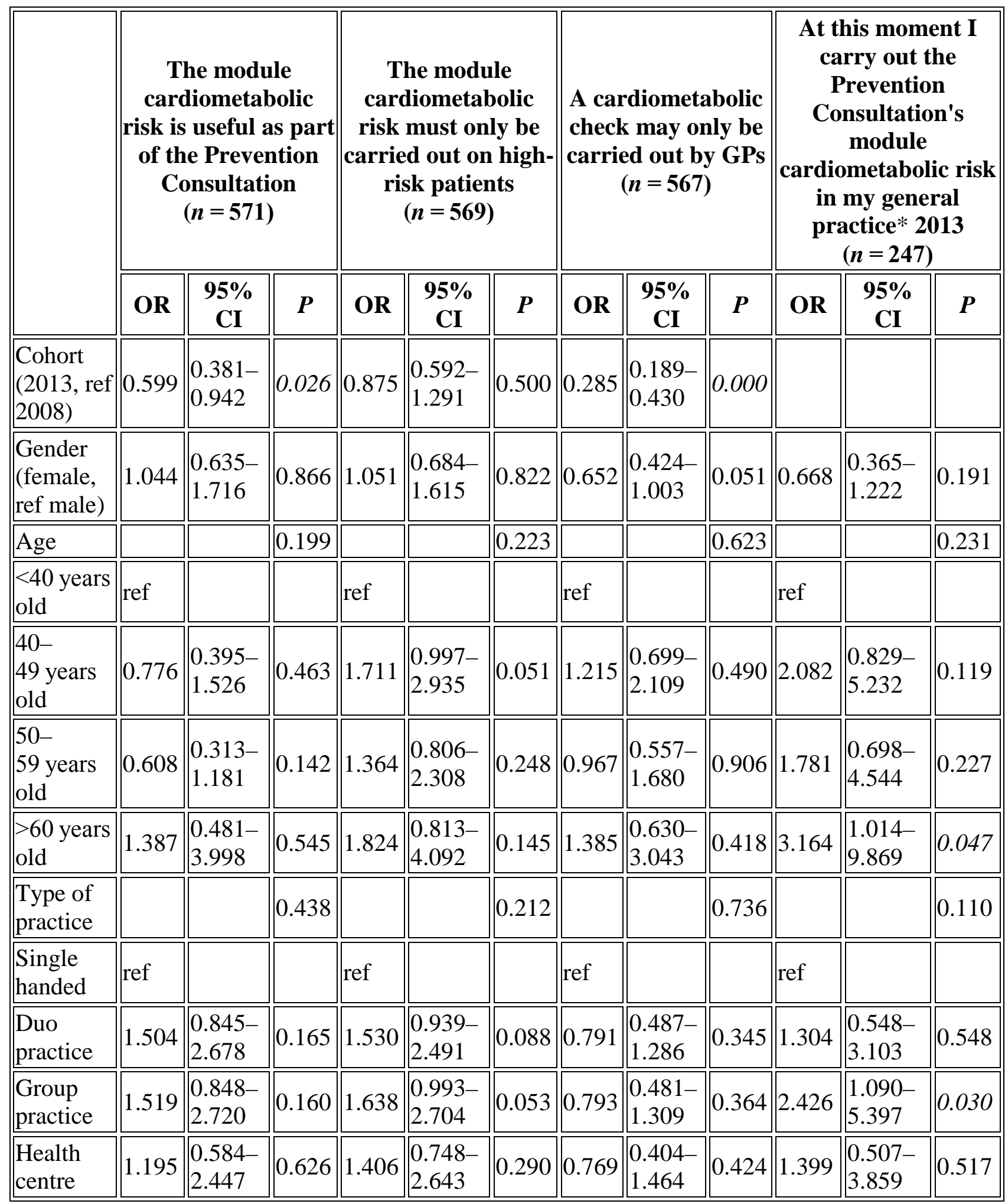


Vos, H.M.M., Delft, D.H.W.J.M. van, Kleijn, M.J.J. de, Nielen, M.M.J., Schellevis, F.G., LagroJanssen, A.L.M. Selective prevention of cardiometabolic diseases in general practice: attitudes and working methods of male and female general practitioners before and after the introdtration of the Prevention Consultation guideline in the Netherlands. Journal of Evaluation in Cliniqalive Practice: 2014, 20(4), 478-485

A comparison before and after the introduction of the Prevention Consultation guideline, controlling for gender differences, age differences and differences in type of practice, a multivariable logistic regression. Italicized $P$-values are statistically significant.

*This question was not asked in the questionnaire in 2008.

CI, confidence interval; GPs, general practitioners; OR, odds ratio.

TABLE 5. GPS' OPINIONS ABOUT HEALTH CARE INSTITUTIONS IN WHICH A CARDIOMETABOLIC CHECK CAN BE PERFORMED

\begin{tabular}{|c|c|c|c|c|c|c|c|c|c|c|c|c|}
\hline \multirow{2}{*}{\begin{tabular}{|c} 
A \\
cardiometabolic \\
check may also \\
be performed \\
at/in the
\end{tabular}} & \multicolumn{3}{|c|}{$\begin{array}{l}\text { Municipal health } \\
\text { services }(n=551)\end{array}$} & \multicolumn{3}{|c|}{ Hospital $(n=555)$} & \multicolumn{3}{|c|}{$\begin{array}{c}\text { Diagnostic } \\
\text { centre/GPs } \\
\text { laboratory } \\
(n=556) \\
\end{array}$} & \multicolumn{3}{|c|}{$\begin{array}{l}\text { Occupational } \\
\text { health service } \\
\qquad(n=553)\end{array}$} \\
\hline & OR & $\begin{array}{c}95 \% \\
\text { CI }\end{array}$ & $\boldsymbol{P}$ & OR & $\begin{array}{c}95 \% \\
\text { CI } \\
\end{array}$ & $\boldsymbol{P}$ & OR & $\begin{array}{c}95 \% \\
\text { CI }\end{array}$ & $\boldsymbol{P}$ & OR & $\begin{array}{c}95 \% \\
\text { CI }\end{array}$ & $\boldsymbol{P}$ \\
\hline $\begin{array}{l}\text { Cohort (2013, ref } \\
\text { 2008) }\end{array}$ & 437 & $\begin{array}{l}1.000- \\
2.067 \\
\end{array}$ & $\mid 0.050$ & 1.922 & $\begin{array}{l}1.329 \\
2.781 \\
\end{array}$ & 0.001 & $\mid 1.614$ & $\begin{array}{l}1.125- \\
2.316 \\
\end{array}$ & $\| 0.009$ & $\|2.227\|$ & \begin{tabular}{|l|}
$1.533-$ \\
3.236 \\
\end{tabular} & 0.000 \\
\hline $\begin{array}{l}\text { Gend } \\
\text { ref m }\end{array}$ & 0.894 & $\begin{array}{l}0.598- \\
1.335\end{array}$ & || 0.582 & 0.844 & $\begin{array}{l}0.561- \\
1.270\end{array}$ & 0.417 & 0.905 & $\begin{array}{l}0.608- \\
1.346\end{array}$ & 0.622 & $\|1.166\|$ & $\begin{array}{l}0.773- \\
1.759\end{array}$ & 0.463 \\
\hline Age & & & 0.551 & & & 0.740 & & & 0.017 & & & 0.359 \\
\hline$<40 y$ & $f$ & & & ref & & & ref & & & ref & & \\
\hline $40-49 y$ & 1.064 & $\begin{array}{l}0.637- \\
1.778\end{array}$ & $\mid 0.811$ & 0.919 & $\begin{array}{l}0.558- \\
1.513\end{array}$ & 0.001 & 1.306 & $\begin{array}{l}0.792- \\
2.153\end{array}$ & $|0.259|$ & $\|1.308\|$ & $\mid \begin{array}{l}0.769- \\
2.222\end{array}$ & 0.322 \\
\hline $50-5$ & 0.927 & $\begin{array}{l}0.554- \\
1.551 \\
\end{array}$ & $\mid 0.772$ & 0.407 & $\begin{array}{l}0.242- \\
0.685\end{array}$ & 0.363 & 0.704 & $\begin{array}{l}0.422- \\
1.175 \\
\end{array}$ & $\|0.179\|$ & $\|1.147\|$ & $\begin{array}{l}0.671- \\
1.960 \\
\end{array}$ & 0.616 \\
\hline$>60 y$ & 1.462 & $\begin{array}{l}0.706- \\
3.030\end{array}$ & $\mid 0.306$ & 0.712 & $\begin{array}{l}0.343- \\
1.481\end{array}$ & 0.452 & 1.453 & $\begin{array}{l}0.702- \\
3.006\end{array}$ & $\mid 0.314$ & $\| 1.882 \mid$ & $\mid \begin{array}{l}0.886- \\
3.996\end{array}$ & 0.100 \\
\hline Type of practice & & & 0.244 & & & 0.107 & & & 0.781 & & & 0.932 \\
\hline Single h & 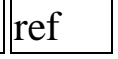 & & & ref & & & ref & & & ref & & \\
\hline Duo & 0.721 & $\begin{array}{l}0.449- \\
1.157\end{array}$ & $\mid 0.175$ & 0.673 & $\begin{array}{l}0.416- \\
1.089\end{array}$ & 0.489 & 0.786 & $\begin{array}{l}0.493- \\
1.253 \\
\end{array}$ & $|0.312|$ & $\|1.025\|$ & \begin{tabular}{|l|}
$0.628-$ \\
1.674 \\
\end{tabular} & 0.922 \\
\hline Group practice & 0.934 & $\begin{array}{l}0.583- \\
1.494 \\
\end{array}$ & $\mid 0.774$ & 0.845 & $\begin{array}{l}0.525- \\
1.361 \\
\end{array}$ & 0.563 & 0.852 & $\begin{array}{l}0.533- \\
1.362 \\
\end{array}$ & 0.503 & $\|1.124\|$ & \begin{tabular}{|l|}
$0.688-$ \\
1.837 \\
\end{tabular} & 0.640 \\
\hline Health centre & 1.272 & $\begin{array}{l}0.709- \\
2.279\end{array}$ & $\mid 0.420$ & 0.836 & $\begin{array}{l}0.456- \\
1.533\end{array}$ & 0.593 & 0.827 & $\begin{array}{l}0.454- \\
1.505 \\
\end{array}$ & $\mid 0.534$ & $\mid 0.933$ & $\begin{array}{l}0.497- \\
1.750 \\
\end{array}$ & 0.82 \\
\hline
\end{tabular}

A comparison before and after the introduction of the Prevention Consultation guideline, controlling for gender differences, age differences and differences in type of practice, a multivariable logistic regression. Italicized $P$-values are statistically significant.

CI, confidence interval; GPs, general practitioners; OR, odds ratio. 